\title{
THE INFLUENCE OF HUMAN RESOURCES COMPETENCY ON EMPLOYEES PERFORMANCE
}

\author{
Kiki Aprilia*1, Nur Zeina Maya Sari ${ }^{2}$, Dedy Sudarmadi ${ }^{3}$ \\ Universitas Langlangbuana, Indonesia*123 \\ kikiaprilla519@gmail.com *1, nurzeina.mayasari@unla.ac.id², \\ dedy.trowulan@gmail.com ${ }^{3}$
}

\begin{abstract}
This study aims to determine how much the Human Resources Competency on Employee Performance Studies at Retail Planet Fashion Bandung. In this study, the dependent variable is employee performance and the independent variable is human resource competency. The method used in this research is descriptive, quantitative, verification method, while the method of data collection done by distributing questionnaires and using sampling methods, namely the purposive sampling method in processing the samples used. The results of this study indicate that there is an influence of the competency of resources on employee performance.
\end{abstract}

Keywords: Human Resources Competency, Employee Performance

\section{INTRODUCTION}

In the face of current business competition, employee performance is very important for the development of the organization, the situation facing the global business environment encourages each organization to achieve every desired goal and consider various obstacles, risks, and competitors, then the organization must make some changes in the face of future conditions to improve effectiveness and efficiency, the success of an organization in making every change seen from how the organization can handle problems that arise as a result of these changes (Suryani \& John, 2018).

Performance is the result of work achieved by a person in performing his duties by predetermined standards (Shaleh, 2018). Furthermore, in general, according to Sulaksono (2015), three factors affect performance, namely: (1) Individual factors: ability as well as background skills, demographics; (2) Psychological factors: perception, attitude, personality, and learning; (3) Organizational factors: resources, compensation, awards, structure, and job design.

According to Priansa (2017) competency is the capacity of employees for the work carried out, namely a collection of abilities, skills, maturity, experience, effectiveness, efficiency, and success in carrying out work responsibilities. Meanwhile, according to Wirawan (2015), human resources are a group of people such as managers, employees, laborers, or people called workers who work in an organization.

Human resource management and employment relations must adopt a pluralist approach and place heavy emphasis on people management, strategy, and context interaction to shape multiple goals (Malik, 2019). Human capital means the organization's employees, described in terms of their training, experience, judgment, intelligence, relationships, and insight the employee characteristics that can add economic value to the organization (Stone, 2019).

Dessler (2020) describes human resource management (HRM) is the process of acquiring, training, appraising, and compensating employees, and of attending to their labor relations, health and safety, and fairness concerns. Every manager needs to perform the "people," or personnel, aspects of management for strategic goals. 


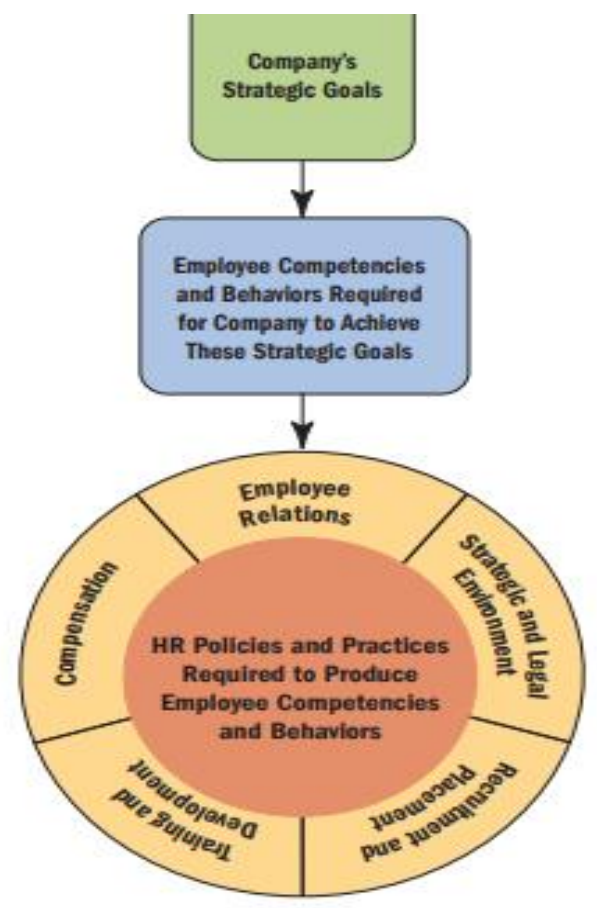

Figure 1. Company Strategic Goals Source: Processed data (2020)
The level of competency of human resources in Pianda (2018) grouped into three levels of competency, namely: (1) Behavioral Tools: (a) Knowledge is the knowledge of information that will be used by a person for a specific field, (b) Skill is a skill of a person in a particular field very well; (2) Image attribute: (a) Social Role is an example of a person's behavior that is influenced and supported by social groups and organizations, (b) Self Image is people's opinion of themselves, identity, behavior, and self-esteem; (3) Personal Characteristic: (a) Traits are a common angle in behaving, (b) Motive is something that triggers one's behavior in a particular field (performance and power); (4) Research Objectives: To know the huge influence of Human Resource Competency on Employee Performance.

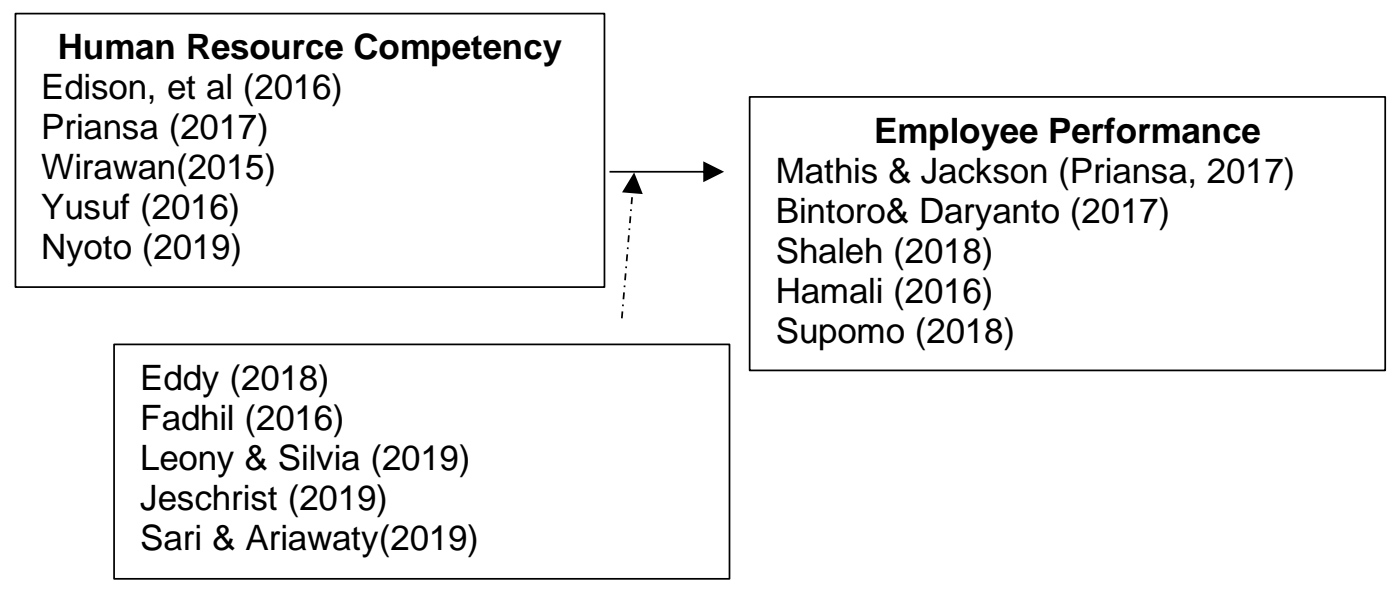

Figure 2. The Formulation of Problems

Source: Processed data (2020)

Based on the formulation of problems, theoretical foundations, and frame of mind above, the authors proposed.

\section{METHODS}

The respondents selected were employees and staff working at Planet Fashion Retail Company who met the criteria. The intended criteria are employees who work using the system and are involved in receiving human resource competencies owned and what factors affect employee performance, then the number of the employee population is as many as 50 people using purposive sampling techniques. Indicators of human resource competency According to Spencer and Spencer in the book Nyoto (2019) competency flow model is based on iceberg approach, namely: Knowledge 
(Knowledge), Skills (Skills), Social Role (Social Role), Traits and Motives (Motives). Employee performance indicators according to Mathis and Jackson (Priansa, 2017) include ability, effort and training, and development. Data collection techniques using the rating scale method with assessment as below: Test the research instrument using a validity test with Pearson Product Moment Correlation and reliability test used is Alpha. The classic assumption tests used are multicollinearity test, autocorrelation test, Heteroskedastisity test, and normality test. The data analysis technique used is the Method Of Interval (MSI).

\section{RESULTS AND DISCUSSION}

Table 1. Classic Assumption Test Results

\begin{tabular}{lll}
\hline \multicolumn{1}{c}{ Classic assumption test } & \multicolumn{1}{c}{ Test results } & \multicolumn{1}{c}{ Conclusion } \\
\hline Multicollinearity Test & Tolerance $(962>0.10)$ & Multicollinearity Free \\
& VIF $(1.039<10.00)$ & Free \\
Autocorrelation Test & DW $(1,685)$ & Autocorrelation Free \\
Heteroscedasticity Test & Data points spread & Heteroscedasticity free \\
Normality Test & Assymp $(0.200>0.05)$ & Normality Free \\
\hline
\end{tabular}

Source: The data is processed by the author (2020)

The table shows that the results of classical assumptions obtained results that data are free. So that it can be used for further analysis in answering research hypotheses.

\section{Multiple Linear Regression Analysis \\ Multiple linear regression analysis aims to determine the influence of}

accounting information system quality variables and human resource competencies on the performance of Retail Planet Fashion Bandung employees. Calculation using SPSS 22 application. The results of multiple linear regression analysis tests can be obtained as follows:

Table 2. Test Results of Multiple Linear Regression Analysis

\begin{tabular}{llllll}
\hline $\begin{array}{l}\text { Human resource } \\
\text { competency }\end{array}$ &, 429 &, 140 &, 418 & 3,607 &, 004 \\
a. Dependent Variable: Employee performance \\
\hline \multicolumn{5}{c}{ Source: The data is processed by the author (2020) }
\end{tabular}

Source: The data is processed by the author (2020)

Based on the results of multiple linear regression tests can be obtained regression equations as follows:

$\mathrm{KK}=0.429 \mathrm{KSDM} 2+\mathrm{e}$

The interpretation is as follows:

The coefficient a: 0.429 variable coefficient of Human Resource Competency is positive, it can be interpreted that the influence of Human Resource Competency on Employee Performance is positive. If the value of Human Resource Competency increases then employee performance will increase by 0.429 .

\section{Correlation Coefficient}

It can be noted that calculation known for the relationship of Human Resource Competency $(\mathrm{X})$ to Employee 
Performance $(Y)$ is $0.505>0.338$, then if it is concluded that there is a relationship or correlation between the variable Human Resource Competency $(\mathrm{X})$ to Employee Performance (Y) including a fairly strong category. The correlation coefficient value also shows a positive number, meaning that the higher the quality of the accounting information system, the level of employee performance will also increase.
The result of human resource competency to employee performance of 0.255 or $25.5 \%$. The rest is influenced by other variables that are not researched.

\section{Hypothesis Test}

The T-test is Human Resource Competency variables, the t-test is related or has no effect on Employee Performance in the test with a level of 0.05 .

\section{Coefficient of Determination}

Table 3. t-test results

\begin{tabular}{ccccc}
\hline $\begin{array}{c}\text { The Coefficient of } \\
\text { Determination }\end{array}$ & T-Count & T-Table & P-Value & Conclusion \\
\hline 0,505 & 3,067 & 2,039 & 0,000 & H0 is rejected \\
\hline \multicolumn{4}{r}{ Source: The data is processed by the author (2020) }
\end{tabular}

Based on the values in the table above, it can be seen that $t$ value 3.067 $>$ t table 2.039, so it can be concluded that $\mathrm{Ho}$ was rejected and $\mathrm{H} 1$ accepted. Therefore, human resource competency variables have a significant effect on Employee Performance.

The Influence of Human Resource Competency on Employee Performance Correlation test results showed the coefficient of determination of human resource competency is 0.255 or $25.5 \%$ and the rest is influenced by variables outside the regression model, this value belongs to a weak category because it has a residual contribution that is largely not researched by researchers. It can be concluded that the value of donations is dominated by variable Human Resource Competencies is $25.5 \%$ compared to the contribution value of the accounting information system quality variable of $22.7 \%$, therefore human resource competencies have a big influence on employee performance. In line with the theory of human resource competency, namely the ability, knowledge, and skills to complete a task. Based on the findings studied, the competency of human resources is very useful because employees can provide ideas and can work with colleagues to create the right work environment to encourage employees to feel that creative and innovative ideas are awaited. Based on the company's findings, the competency of human resources is not getting a good appreciation for its work.

\section{CONCLUSION}

Human resource competencies influence employee performance at Retail Planet Fashion. This is because the competency of human resources is good. After all, employees can provide ideas and can work with colleagues so that they create the right work environment to encourage employees to feel that their creative and innovative ideas are awaited to increase employee work productivity at Retail Planet Fashion.

\section{REFERENCES}

Bintoro, \& Daryanto. (2017). Manajemen Penilaian Kinerja Karyawan. Yogyakarta: Gava Media.

Dessler, G. (2020). Human resource management. New Jersey: Prentice Hall, Inc. 
Eddy, Yunus (2018) Pengaruh Kompetensi Sumber Daya Manusia Terhadap Kinerja Pegawai KPPBC Tipe Madya PABEAN Tanjung Perak Surabaya

Edison, E. (2016). Manajemen Sumber Daya Manusia. Bandung: Alfabeta.

Fadhil, M. (2016). Pengaruh Kompetensi Sumber Daya Manusia Terhadap Kinerja Pegawai Pada Balai Latihan Kerja Industri Makasar . p-ISSN: 23550538.

Hamali, A. Y. (2016). Pemahaman Manajemen Sumber Daya Manusia. Jakarta: Center for Academic Publishing Service. Indonesia.

Jeschrist, Laoh. (2019). Pengaruh Karakteristik Individu dan Kompetensi Sumber Daya Manusia Terhadap Kinerja Karyawan Pada Usaha Rumah Kopi Di Manado . ISSN 2303-1174

Leony Hoki, \&. Silvia, Sofyan. 2019. Pengaruh Kompetensi Sumber Daya Manusia dan Kedisiplinan Terhadap Kinerja Karyawan Pada PT Sumber Sukses Rezeki. pISSN : 2549-5836

Malik, A. (2019). Strategic Human Resource Management and Employment Relations: An International Perspective. Work Design and HR Planning: $A$ Strategic Perspective.

Nyoto. (2019). Manajemen Sumber Daya Manusia. Sidoarjo: Uwais Inspirasi
Pianda, D. (2018). Kinerja Guru. Sukabumi: CV Jejak.

Priansa, D. J. (2017). Manajemen Kinerja Kepegawaian. Bandung: Pustaka Setia.

Sari, N.Z.M.,\& Ariawaty, R.R.N. (2019). Management Information System influenced by the competence of human resources employee of civil apparatus (Asn) West Java. International Journal of Scientific \& Technology Research, 8(10), pp.1019-1021.

Shaleh, M. (2018). Komitmen Organisasi Terhadap Kinerja Karyawan. Makasar: Aksara Timur.

Stone, R. J. (2019). Human Resource Management: Personnel Human Resource Management. Harvard Business Review, 13.

Sulaksono, H. (2015). Budaya Organisasi dan Kinerja. Yogyakarta: Deepublish.

Supomo, E. N. (2018). Manajemen Sumber Daya Manusia. Bandung: Yrama Widya.

Suryani, N. K., \& John. (2018). Kinerja Organisasi. Yogyakarta: Deepublish..

Wirawan. (2015). Manajemen Sumber Daya Manusia Indonesia. Depok: RajaGrafindo Persada.

Yusuf, B. (2016). Manajemen Sumber Daya Manusia Di Lembaga Keuangan Syariah. Jakarta: RajaGrafindo Persada. 